\title{
SOURCES OF ELECTRICITY LAW IN INDIA: AN ANALYTICAL STUDY
}

Dr. Ganesh Dubey, Head and Director,

Associate Professor, Institute of Law, Jiwaji University, Gwalior.

email: dr.ganeshdubey27@gmail.com

Anchit Verma, Ph.D. Scholar,

Institute of Law, Jiwaji University, Gwalior.

Electronic version

URL: http://www.researchambition.com

DOI: https://doi.org/10.53724/ambition/v6n1.04

ISSN: 2456-0146

Vol. 6, Issue-I, August 2021

Page No. 10-13

Publisher

Welfare Universe

email: publish2017@gmail.com

CResearch Ambition: An International Multidisciplinary e-Journal 2021. This Open Access article is published under a Creative Commons Attribution Non-Commercial 4.0 International License https://creativecommons.org/licenses/by-nc/4.0/, which permits non-commercial reuse, distribution, and reproduction in any medium, provided the original work is properly cited. For citation use the DOI. For commercial re-use, please contact editor email:- publish2017@gmail.com By accessing the work you hereby accept the Terms. Non-commercial uses of the work are permitted without any further permission from Research Ambition: An International Multidisciplinary eJournal provided the work is properly attributed. 


\section{SOURCES OF ELECTRICITY LAW IN INDIA: AN ANALYTICAL STUDY}

\section{${ }^{*}$ Dr. Ganesh Dubey \\ ${ }^{* *}$ Anchit Verma}

\section{Abstract}

To strengthen pillars of technology for any nation, electricity as power plays significant role. Thus it is necessary to groom concern laws and by-laws for the electricity industry. Purpose of the research paper is to look into very basic set-up for energy laws on one hand and to study fundamentals of law and Indian legal system which covers introduction of law, its sources, and fundamental features, substantive and procedural laws in connection to power sector.

Keywords: The Electricity Act, 2003, 'business efficacy, State Electricity Regulatory Commission, National Electricity Policy, Central Electricity Regulatory Commission.

\section{Introduction}

Revolution in the technology has brought up electricity rules and regulations in the pole position. To regulate generation, transmission and distribution of electricity the very first legislation was enacted in India as Electricity Act, 1887. Purpose of the Act was to protect property and individuals from risk and injury and for other purposes as well. The Indian Electricity Act, 1903 replaced Act of 1887, which continued for six years but due to some commercial, electro technical issues in the Act, a bill was passed on 18th March by legislative council and The Indian Electricity Act, 1910 came into force on 1st January, 1911. Series of Electricity Amendment Act were introduced time to time and presently we have 'The electricity Act, 2003' and draft of Electricity Bill 2020 is pending.

Before dive into technicality of the Act, concern study of Indian legal system including Indian Constitution, role of parliament, fundamental features, substantive and procedural laws related to electricity required to be done.

\section{Role Of The Constitution Of India}

The Constitution of India is the supreme law of the nation. It lays down demarcating framework which is ultimate political structure, procedure, code, duties and power of government and citizen of India. The chairman of drafting committee and chief architect of The Indian Constitution designed this document so well that it has constitutional supremacy rather than parliamentary supremacy. Fundamental rights ${ }^{1}$, Directive Principles of State policy ${ }^{2}$, Fundamental Duties ${ }^{3}$ on one side and Relations between the union and the states ${ }^{4}$, Trade and commerce within India ${ }^{5}$, arrangements of tribunals ${ }^{6}$ on the other side makes our constitution highly composed. In the schedule of the constitution of India subjects sets out on which the State Legislature and the Parliament can frame out legislation. ${ }^{7}$ The subjects are divided into State, Union and Concurrent list. Both houses can legislate upon the subjects given under concurrent list. Electricity ${ }^{8}$ and Taxes on the consumption or sale of electricity ${ }^{9}$ listed in the seventh schedule is covered under concurrent list and state list respectively. Thus any act, rules or regulations made by appropriate authority have a force of constitution.

\footnotetext{
${ }^{*}$ Head and Director, Associate Professor, Institute of Law, Jiwaji University, Gwalior.

${ }^{* *}$ Ph.D. Scholar, Institute of Law, Jiwaji University, Gwalior.

${ }^{1}$ The Constitution of India, Part III, art. 14-32.

${ }^{2}$ The Constitution of India, Part IV, art. 37-51.

${ }^{3}$ The Constitution of India, Part V, art. 51A (42 ${ }^{\text {nd }}$ Amendment, 1976).

${ }^{4}$ The Constitution of India, Part XI, art. 245-255.

${ }^{5}$ The Constitution of India, Part XIII, art. 301-305.

${ }^{6}$ The Constitution of India, Part XIVA, art 323A-323B (42 ${ }^{\text {nd }}$ Amendment, 1976).

${ }^{7}$ The Constitution of India, Seventh Schedule, art. 246

${ }^{8}$ The Constitution of India, Seventh Schedule, List III, Entry 38

${ }^{9}$ The Constitution of India, Seventh Schedule, List II, Entry 53
} 


\section{Role Of State Legislature And Parliament}

India has a parliamentary form of governing system with a bicameral legislature. Part $\mathrm{V}$ of the Indian Constitution provides for parliamentary functions. Legislative, executive, financial, constituent, judicial, electoral powers provided by the Constitution to the parliament.

Resonation passed by Rajya Sabha ${ }^{10}$, at the time of national emergency ${ }^{11}$, on the request of two or more state ${ }^{12}$, in order to give effect to international conventions treaties and agreements ${ }^{13}$, at the time of President rule ${ }^{14}$ parliament exercises its legislative power.

Ministry of Power plays vital role to draft, pass and implement legislations, rules and regulations concern with electricity production, transmission, generation and delivery and also in maintenance of power projects. The ministry formed on $2^{\text {nd }}$ July 1992 and has its headquarters in Shram Shakti Bhawan, Rafi Marg, New Delhi. ${ }^{15}$

\section{Substantive And Procedural Law}

Substantive laws are statutory law which defines and creates rights. It deals with the legal bond between individuals or the individuals and state. It is codified to deal with substance of the case, how the charges and facts are handled and dealt respectively. Indian Penal Code, Law of Contract, Law of Property, Specific relief Act are some instance of substantive law. Procedural law is comprised with set of rules which governs the proceedings of the court in civil as well as criminal and administrative proceedings. Basically it provides state to a machinery to enforce substantive rights on the people. Criminal procedure Code, Evidence Act, Civil Procedure Code are some examples of procedural law.

\section{i. $\quad$ Substantive Civil and Commercial Law for Energy disputes}

The Indian Contract Act, 1872 primarily look after contractual issues of power sector whenever parties to the contract signs the agreement and explicitly agrees to enter into contract. But whenever there is unclear expression of explicit term of contract and where intention of the parties is vague, occasionally court applies the 'business efficacy' test which is a method to interpret and achieve intend of the parties acting as a discreet entrepreneur. The Supreme Court of India held that in five circumstances implied conditions may be taken into consideration to interpret a contract when- it appears equitable and reasonable; it is essential to give business efficacy to the contract; clear expression can be drawn out from conditions; words go without saying; express term of the contract must not be contradicted by the conditions. ${ }^{16}$

Indian Penal Code looks into criminal liability of an individual; it may be theft, nuisance and any other act punishable by the state.

\section{ii. Procedural Law for Power Sector}

Code of Civil Procedure, 1908 plays prime role in proceedings of power sector. Appropriate commission reserves same power as civil court for the purpose of proceedings or inquiry under the Act. ${ }^{17}$ On the other side Appellate Tribunal is not bound by the process laid down by CPC, 1908 but shall act upon principles of natural justice. ${ }^{18}$ Further any aggrieved person due to decision of Appellate Tribunal may appeal to the Apex Court within sixty days from the date of decision. ${ }^{19}$

\section{Electricity Act 2003}

For the purpose of transformation of power sector Parliament of India enacted The Electricity Act, 2003 with effect from $2^{\text {nd }}$ June. Generation, transmission, distribution and power trading are well dealt in the Act.

There are some key features of the Act-

\footnotetext{
${ }^{10}$ The Constitution of India, s. 249

${ }^{11}$ The Constitution of India, s. 352

${ }^{12}$ The Constitution of India, s. 252

${ }^{13}$ The Constitution of India, s. 253

${ }^{14}$ The Constitution of India, s. 256

${ }^{15}$ Ministry of Power, Government of India, available at: www.powermin.nic.in (last visited on August 10, 2020).

${ }^{16}$ Nabha Power Limited v Punjab State Power Corporation Limited \& Anr (2018) 11 SCC 508

${ }^{17}$ The Electricity Act 2003, s. 94

${ }^{18}$ The Electricity Act 2003, s. 120

${ }^{19}$ The Electricity Act 2003, s. 125 read with Code of Civil Procedure,1908, s. 100 
- Generation of electricity is being de-licensed and captive generation of electricity permitted freely, so that any generating company may maintain, operate and establish a generating station without obtaining any sort of license but the company should comply with technical connectivity of the grid. ${ }^{20}$

- For integrated, economical and efficient supply and transmission of electricity, the Central Government may time to time region wise make demarcation of country and modify it as per requirement.

- Mandatory sitting of State Electricity Regulatory Commission

- Against decision of State Electricity Regulatory Commission and Central Electricity Regulatory Commission, aggrieved can approach to an Appellate Tribunal.

- To counter electricity theft provisions of the Act made harsher.

- $\quad$ Tariff Policy and National Electricity Policy has to be prepared by Central Government.

\section{Electricity Regulatory Commissions}

i. CERC

The Central Electricity Regulatory Commission is a statutory body and key regulator in the field of power sector in India, it has quasi-judicial status. ${ }^{21}$ On 24th July, 1998 the Commission was constituted underneath Ministry of Power's Electricity Regulatory Commissions Act, 1998 for regulation of tariffs for electricity, policies for subsidies etc. prime function of CERC is to regulate tariff for power generating companies either with in control of Government of India or any other power generating company. ${ }^{22}$

The commission is also exercising some advisory functions ${ }^{23}$ -

- $\quad$ Preparation of Tariff and National Electricity Policy. ${ }^{24}$

- $\quad$ To promote economy, efficiency and competition within electricity industry.

- To encourage investment in the industry of electricity.

\section{ii. SERC}

State Electricity Regulatory Commission is a body established by a state government under Electricity Regulatory Commissions Act, 1998. ${ }^{25}$ The commission is a body corporate, having common seal and perpetual succession along with power to dispose, hold and acquire immovable and movable property both. ${ }^{26}$

Function of State Commission are as follows ${ }^{27}$.

- It determines tariff for transmission, supply, generation and wheeling of power in bulk, wholesale or retail, within in a state.

- It regulates electricity procurement and purchase process of distribution licensees.

- It facilitates state to state transmission and rotation of electricity.

- It adjudicates upon issues between the licensees and electricity generating companies and refers such issue for arbitration.

\section{Electricity Amendment Act 2020}

For the amendment of Electricity Act 2003 Ministry of Power issued an amendment draft and advised interested parties to submit their remarks, objections and suggestions till $5^{\text {th }}$ June, 2020. Highlights of the bill as follows-

- $\quad$ The upcoming Act may be titled as Electricity Act, 2003.

${ }^{20}$ The Electricity Act 2003, s. 73.

${ }^{21}$ The Electricity Act 2003, s. 76.

${ }^{22}$ Ministry of Power (India): https://en.wikipedia.org/wiki/Ministry_of_Power_(India)

${ }^{23}$ The Electricity Act 2003, s. 81.

${ }^{24}$ National Electricity Policy: https://en.wikipedia.org/wiki/National_Electricity_Policy

${ }^{25}$ Electricity Regulatory Commissions Act, 1998, s. 17

${ }^{26}$ The Electricity Act 2003, s. 82.

${ }^{27}$ The Electricity Act 2003, s. 86. 
- The Act shall extent to whole India. ${ }^{28}$

- A clause for cross border trade is added to the Amendment Act which will cover, export and import of electricity. ${ }^{29}$

- Distribution of sub-Licensee introduced which includes- a person authorized and recognized by distribution licensee and shall require permission from SERC. ${ }^{30}$

- Arrangement to formulate NREP (National Renewable Energy Policy) in consultation with State government by the Central government. Objective of NREP would be- to promote the generation of power from renewable sources of energy and to recommend minimum present of the electricity purchase from hydro and renewable sources. ${ }^{31}$

- In upcoming there will be no need obtain separate license for franchisee.

- $\quad$ National Load Dispatch Centre (NLDC) will play additional roles, such as ${ }^{32}$ -

$>$ Will be responsible for best dispatch and scheduling of electricity in across country in various regions.

$>$ The National Load Dispatch Centre may give directions and exercises such control and supervision as may be requires for the security and safety of national grid and for ensuring the solidity of grid operation in the entire country.

$>$ Every Regional Load Dispatch Centre (RLDC), State Load Dispatch Centre (SLDC), generating company, licensee, generating station, sub-station and any other individual connected with the operation of the energy system shall fulfill the directions issued by the National Load Dispatch Centre (NLDC).

- Transmission Charges added under open access and surcharge may be specified by Central Commission and State Commission respectively. ${ }^{33}$

- There will be reduction in cross-subsidies and surcharges by SERCs in the manner as provided in Tariff Policy. The purpose of amendment in this regard is to withdraw the powers of SERC to increasingly reduce Compact SubStation (CSS) and instructs them to abide by National Tariff Policy (NTP) to lessen CSS. ${ }^{34}$

There are many other changes proposed in the amendment act in order to make electricity regulations more effective, smooth, productive and efficient.

\section{Conclusion}

The Constitution of India on one hand makes it crystal clear that what power will be inherited by which government in this parliamentary system, on other hand IPC, CPC, CRPC and other procedural and sustentative legislations playing supportive role to look into and resolve any issue related to energy segment. In Electricity sector aim of the government of India is to make avail access to reliable, affordable modern energy by amending Electricity Act, $2003 .{ }^{35}$ For this purpose major changes going to be happen which will includes' the appointment of distribution sub-franchisees, the constitution of the Electricity Contracts Enforcement Authority, rationalization of tariffs and advancement of an comprehensive National Renewable Energy Policy. ${ }^{36}$

$* * * * * * * * * * * * * * * * * * * * * * * * * *$

\footnotetext{
${ }^{28}$ Electricity Amendment Act 2020, s. 1(2) read with The Constitution of India, art. 370 (abrogated).

${ }^{29}$ Electricity Amendment Act 2020, s. 2(15a).

${ }^{30}$ Electricity Amendment Act 2020, s. 2(17a).

${ }^{31}$ Electricity Amendment Act 2020, s. 3A.

${ }^{32}$ Electricity Amendment Act 2003, s. 26 after addition of Electricity Amendment Act 2020, s. 3A.

${ }^{33}$ Electricity Amendment Act 2003, s. 38 (d)(ii); 39(2)(d)(ii).

${ }^{34}$ Electricity Amendment Act 2003, s. 42

${ }^{35}$ Ministry of Heavy Industries \& Public Enterprises Government of India, Indian Electrical Equipment Industry Mission Plan 2012-2022 (April, 2013).

${ }^{36}$ Draft Electricity Amendment Act - 2020.
} 